\title{
IMPLEMENTASI PSAK 16 PADA ENTITAS PERBANKAN BUMN
}

\author{
Panubut Simorangkir \\ ABFI Perbanas Jakarta \\ panubut@perbanas.id
}

\begin{abstract}
Fixed assets are certainly instrumental to the activities of a company, for service companies, for trading companies, as well as industrial companies. Value on fixed assets is not small. Therefore, it affects the company both in the statement of financial position and profit and loss of the company. The cost on a fixed asset will decrease due to the usage of the property, plant and equipment. The provisions governing property, plant and equipment are listed in PSAK 16 (convergence with IAS 16). The results of this research and analysis that have been done in this research, it can be concluded that the implementation of PSAK 16 in state owned enterprises (BUMN) banking industry industry for the year 2014-2015 can be done smoothly although there are difficulties in the stages to ensure the occurrence of impairment and market pricing. In general, all $B U M N$ entities have applied PSAK 16 in accordance with the appropriate.

Keywords :Fixed Assets, Cost Model, Revalution Model, Impairment
\end{abstract}

\section{LATAR BELAKANG}

Buku Standar Akuntansi Keuangan (SAK) senantiasa di revisi, yang kesemuanya itu bertujuan untuk menampung perobahan dalam dunia bisnis. Buku SAK berisi Pernyataan Standar Akuntansi Keuangan (PSAK) yang menjadi pedoman bagi setiap entitas dalam mencatat dan menyiapkan laporan keuangannya. Pengelolaan aset secara optimal memengaruhi pencapaian tujuan perusahaan. Pada umumnya aset yang dimiliki oleh perusahaan terdiri atas aset lancar atau aset tetap. Kedua aset ini mempunyai peranan sangat penting bagi perusahaan, aset lancar merupakan harta yang dapat dikomsumsi atau mudah dicairkan sedangkan aset tetap adalah sarana penunjang yang dimiliki perusahaan untuk memperlancar kegiatan operasional perusahaan, tidak untuk diperjualbelikan dan merupakan pengeluaran perusahaan yang relatif besar dan memiliki masa manfaat lebih dari satu tahun / satu periode akuntansi. Aset tetap tentu sangat berperan bagi kegiatan suatu perusahaan, bagi perusahaan jasa, bagi perusahaan dagang, maupun perusahaan industri. Nilai pada aset tetap tidaklah kecil. Oleh karena itu, sangatlah mempengaruhi perusahaan baik di neraca maupun laba rugi perusahaan. Nilai perolehan pada suatu aset tetap akan mengalami penurunan karena adanya pemakaian atas aset tetap tersebut. Teraspirasi oleh penelitian oleh Lapointe (2011) di Kanada serta penelitian Monday (2009) tentang implementasi IAS 16, hanya saja bahwa penelitian ini akan memfokuskan implementasi IAS 16 pada industri perbankan. Ketentuan - ketentuan yang mengatur mengenai aset tetap tercantum di dalam IAS 16 yang menyatakan antara lain bahwa aset tetap adalah aset berwujud yang dimiliki untuk digunakan dalam produksi atau penyediaan barang atau jasa untuk direntalkan kepada pihak lain atau untuk tujuan administratif dan digunakan selama lebih dalam satu periode. Biaya perolehan (cost) adalah jumlah kas atau setara kas yang dibayarkan atau nilai wajar dari imbalan lain yang diserahkan untuk memperoleh suatu aset pada saat perolehan atau konstruksi atau, jika diterapkan, jumlah yang diatribusikan ke aset pada saat pertama kali diakui sesuai dengan persyaratan tertentu dalam PSAK yang lain.

Sasaran penelitian ini adalah bagaimana implementasi IAS 16 dan konsistensi penerapan terkait aset tetap dalam laporan keuangan perusahaan industri perbankan BUMN yang terdaftar di BEI. Sedangkan tujuan penelitian ini adalah untuk menganalisis implementasi IAS 16 terkait aset tetap serta implikasinya terhadap laporan keuangan perusahaan industri perbankan BUMN yang terdaftar di BEI, serta memperoleh gambaran umum 
terkait konsistensi perusahaan industri perbankan BUMN yang terdaftar di BEI dalam penerapan aset tetap.

Dari penjabaran di atas menjelaskan bahwa penyusunan laporan keuangan sudah diatur sedemikian rupa terutama berkaitan dengan aset atau aset yang di atur dalam IAS 16. Penelitian ini akan memfokuskan pada implementasi IAS 16 dalam perusahaan industri perbankan BUMN yang terdaftar di BEI. Judul penelitian ini adalah "Implementasi

\section{Standar Akuntansi Berbasis IFRS (IAS 16)"}

\section{STUDI PUSTAKA}

Konvergensi IFRS merupakan salah satu kesepakatan pemerintah Indonesia sebagai anggota G20, hasil dari pertemuan pemimpin negara G20 di Washington DC pada 15 November 2008. Adapun tujuan dari kesepakatan tersebut adalah memperkuat transparansi dan akuntabilitas, memperkuat regulasi, pasar keuangan yang berintegritas, memperkuat kembali kerjasama internasional dan memperbaharui institusi keuangan internasional. IAS 16 membahas tentang Property, Plant and Equipment yang di dalam implementasinya berkaitan erat dengan IAS 36 tentang Impairment.

Rudianto (2012:256) mengatakan bahwa aset tetap merupakan barang berwujud milik perusahaan yang sifatnya relatif permanen dan digunakan dalam kegiatan normal perusahaan, bukan untuk diperjualbelikan. Hal ini berarti bahwa aset adalah sarana atau sumber daya ekomomik yang dimiliki oleh entitas. Selanjutnya aset dapat di kategorikan menjadi aset berwujud (tangible assets) dan aset takberwujud (intangible assets). Aset tetap sangat berperan penting dalam kegiatan operasional perusahaan dan aset tetap tersebut harus selalu ada demi keberlangsungan kegiatan operasional perusahaan.

Menurut Pernyataan Standar Akuntansi Keuangan (PSAK) 16 aset tetap adalah aset berwujud yang:

1. Dimiliki untuk digunakan dalam produksi atau penyediaan barang atau jasa, untuk direntalkan kepada pihak lain, atau untuk tujuan administratif; dan

2. Diperkirakan untuk digunakan selama lebih dari satu periode.

Aset tetap memiliki sifat yang rentan terhadap penurunan kapasitas sejalan dengan penggunaan atau pemanfaatannya. Oleh karena itu, perusahaan harus menyajikan informasi yang akurat mengenai nilai aset tetap nya sesuai dengan ketentuan yang berlaku saat ini yang menggunakan fair value. Adanya penyusutan bermanfaat sebagai perusahaan untuk mencerminkan nilai buku yang sebenarnya atas aset tetap yang disusutkan. Kieso \& Weygandt (2014) mengatakan bahwa pengertian dari penyusutan aset tetap adalah proses akuntansi untuk mengalokasikan harga pokok (cost) aset berwujud pada beban dengan cara yang sistematik dan rasional dalam periode-periode yang mengambil manfaat dari penggunaan aset tersebut.

Dari macam-macam aset tetap, untuk tujuan akuntansi dilakukan penggolongan sebagai berikut:

1. Aset tetap yang umur manfaatnya tidak terbatas seperti tanah untuk letak perusahaan, pertanian dan peternakan.

2. Aset tetap yang umur manfaatnya terbatas dan apabila sudah habis masa penggunaannya dapat diganti dengan aset yang sejenis, misalnya bangunan, mesin, alat-alat, mebel dan lain-lain.

3. Aset tetap yang umur manfaatnya terbatas dan apabila sudah habis masa penggunaannya tidak dapat diganti dengan aset yang sejenis, misalnya sumber-sumber alam seperti hasil tambang dan lain-lain.

\subsection{Biaya Perolehan Aset Tetap}

Menurut PSAK 16 paragraf 06 bahwa biaya perolehan aset tetap adalah jumlah kas atau setara kas yang dibayarkan atau nilai wajar dari imbalan lain yang diserahkan untuk memperoleh suatu aset pada saat perolehan atau konstruksi, atau, jika dapat diterapkan, jumlah yang diatribusikan pada saat aset ketika pertama kali diakui. Pengakuan Biaya perolehan aset tetap diakui sebagai aset tetap jika dan hanya jika: 
1. Kemungkinan besar entitas akan memperoleh masa manfaat ekonomik masa depan dari nilai aset tersebut.

2. Biaya perolehan dapat diukur secara andal.

Namun adakalanya dicatat sebagai biaya perolehan meskipun tidak secara langsung meningkatkan manfaat ekonomik dari suatu aset, tapi pengeluaran tersebut diperlukan oleh entitas untuk memperoleh manfaat ekonomik masa depan dari aset lain

\subsection{Penilaian Aset Tetap}

Menurut IAS 16 tahun 2012 penilaian aset tetap dapat menggunakan 2(dua) yakni model harga perolehan (cost model) atau model revaluasian. Dengan metode biaya aset tetap tersebut dicatat pada harga perolehan dikurangi dengan akumulasi penyusutan dan akumulasi rugi penurunan nilai aset. Dengan metode revaluasian suatu aset tetap nilai wajarnya diukur secara andal sehingga harus dicatat pada jumlah revaluasian, yaitu nilai wajar pada tanggal revaluasi dikurangi akumulasi penyusutan dan akumulasi rugi penurunan nilai yang terjadi setelah tanggal revaluasi. Revaluasi atas aset tetap harus dilakukan dengan keteraturan yang cukup reguler untuk memastikan bahwa jumlah tercatat tidak berbeda secara material dari jumlah yang ditentukan dengan menggunakan nilai wajar pada periode pelaporan. Dilihat dari kemudahan untuk mendapatkan informasi tentang harga pasar (market value) suatu aset tertentu, Rudianto (2012:258) mengatakan bahwa mengelompokkan aset ke dalam tiga tingkatan, yaitu :

1. Aset yang harganya selalu tersedia setiap saat dan mudah diketahui, seperti harga surat berharga di bursa efek.

2. Aset yang harganya tidak selalu tersedia setiap saat dan tidak langsung diketahui dengan mudah, seperti harga properti dan berbagai mesin yang dimiliki oleh perusahaan.

3. Aset yang harga pasarnya tidak tersedia dan tidak mudah diketahui. Aset semacam ini dimiliki oleh perusahaan karena pesanan khusus akibat keunikan usaha perusahaan tersebut atau karena hibah yang diberikan pihak lain.

Perusahaan dapat memlih salah satu model penilaian aset tetap tersebut sebagai kebijakan akuntansi dan menerapkan kebijakan tersebut pada seluruh aset tetap dalam kelompok yang sama. Akan tetapi IAS 16 tidak mengizinkan suatu entitas menerapkan dua model yang berbeda untuk kelompok aset tetap.

\subsection{Revaluasi Aset Tetap}

Purba (2013) mengatakan bahwa revaluasi aset tetap adalah penilaian kembali aset tetap perusahaan yang diakibatkan adanya kenaikan nilai aset tersebut dipasaran atau karena rendahnya nilai aset tetap dalam laporan keuangan perusahaan yang disebabkan oleh devaluasi atau sebab lain. Revaluasi dilakukan secara cukup reguler untuk memastikan bahwa jumlah tercatat tidak berbeda secara material dengan jumlah yang ditentukan dengan menggunakan nilai wajar pada akhir periode pelaporan. Frekuensi revaluasi bergantung pada perubahan nilai wajar dari aset tetap yang direvaluasi. Jika nilai wajar dari aset yang direvaluasi berbeda secara material dengan jumlah tercatatnya, maka revaluasi lanjutan perlu dilakukan. Beberapa aset tetap mengalami perubahan nilai wajar secara signifikan dan fluktuatif sehingga perlu direvaluasi secara Tahunan. Revaluasi Tahunan tersebut tidak perlu dilakukan untuk aset tetap yang perubahan nilai wajarnya tidak signifikan. Namun demikian, aset tetap tersebut mungkin perlu direvaluasi setiap tiga atau lima tahun sekali. Apabila suatu aset tetap direvaluasi, maka seluruh aset tetap dalam kelompok yang sama juga harus direvaluasi.

\subsection{Penghentian dan Pelepasan Aset Tetap}

Pelepasan aset tetap dapat dilakukan dengan berbagai cara, yaitu:

1. Pembuangan aset tetap

Dalam hal ini perkiraan aset tetap dan akumulasi penyusutan harus dihapuskan dengan mengkredit perkiraan aset tetap yang bersangkutan sebesar harga perolehan dengan mendebit perkiraan akumulasi penyusutan sampai saat pelepasannya. Apabila terdapat nilai sisa, maka dicatat sebagai rugi atas pelepasan aset tetap. 


\section{Penjualan aset tetap}

Perusahaan kerap kali melepas aset tetapnya dengan menjual aset tetap tersebut. Dengan membandingkan nilai buku aset tetap (biaya perolehan dikurangi akumulasi penyusutan) dengan harga jualnya (nilai realisasi bersih bilamana terdapat beban penjualan), perusahaan bisa saja mendapat keuntungan atau menanggung kerugian. Apabila harga jual lebih besar dari nilai buku aset tetap maka perusahaan memperoleh keuntungan, sebaliknya apabila harga jual dibawah nilai buku maka perusahaan menderita kerugian.

3. Pertukaran aset tetap

Prosedur untuk pertukaran aset tetap sama sepeti perolehan aset tetap dengan pertukaran yang telah diuraikan sebelumnya.

Menurut IAS No.16 Tahun 2012 tentang Aset Tetap, jumlah tercatat aset tetap dihentikan pengakuannya pada saat dilepas atau ketika tidak terdapat lagi manfaat ekonomi masa depan yang diharapkan dari penggunaan atau pelepasannya. Pelepasan aset tetap dapat dilakukan dengan berbagai cara (misalnya: dijual, disewakan berdasarkan sewa pembiayaan, atau disumbangkan). Keuntungan atau kerugian yang timbul dari penghentian pengakuan aset tetap dimasukkan dalam laba rugi pada saat aset tersebut dihentikan pengakuannya. Untuk memilih metode penyusutan dan estimasi umur manfaat aset diperlukan pertimbangan. Oleh karena itu, pengungkapan metode yang digunakan dan estimasi umur manfaat atau tarif penyusutan memberikan informasi bagi pengguna laporan keuangan dalam mengkaji kebijakan yang dipilih manajemen dan dapat pula menjadi perbandingan bagi perusahaan lain. Jika sebuah aset tetap disajikan pada jumlah revaluasian, maka harus dijelaskan tanggal revaluasian, penialai yang dipakai m metode yang digunakan dan surplus revaluasi jika ada.

\subsection{Penelitian Terdahulu}

Beberapa penelitian telah dilakukan mengenai perlakuan aset tetap dalam sebuah perusahaan dan pengaruhnya terhadap laporan keuangan, Namun terdapat banyak variasi hasil dari penelitian - penelitian terdahulu mengenai pengaruh perlakuan aset tetap perusahaan terhadap laporan keuangan.

Lacointe (2011) yang melakukan penelitian tentang implementasi IAS 16 dan IAS 41 pada perusahaan manufaktur di Kanada

Megawati \& Suhadak, (2014) meneliti PT. Perkebunan Nusantara X (Persero) Pabrik Gula Meritjan Kediri pada tahun 2012 yang menemukan adanya kesalahan yang mendasar saat pencatatan perolehan aset tetap baru yang masih dalam tahap penyelesaian atau belum terealisasikan dan belum siap digunakan untuk keperluan kegiatan operasional perusahaan. Selain itu ditemukan ada beberapa aset tetap yang tidak disusutkan.

Budiman, Pangemanan, \& Tangkuman (2014) meneliti PT. Hasjrat Multifinance Manado 2012, yang mencatat perolehan aset tetap, dicatat sebesar harga beli sedangkan biayabiaya yang dikeluarkan sehubungan dengan perolehan aset tetap tersebut dianggap sebagai biaya operasional.

\subsection{Kerangka Pemikiran}

Dari penjabaran di atas telah dapat di simpulkan bahwa implementasi PSAK 16 terkait aset tetap dapat mempengaruhi laporan keuangan perusahaan dari segi pengakuan, pengukuran/penilaian, pengungkapan dan penyajian. Maka dari semua hal yang telah di jabarkan dapat dibuat kerangka pemikiran dalam penelitian ini seperti:

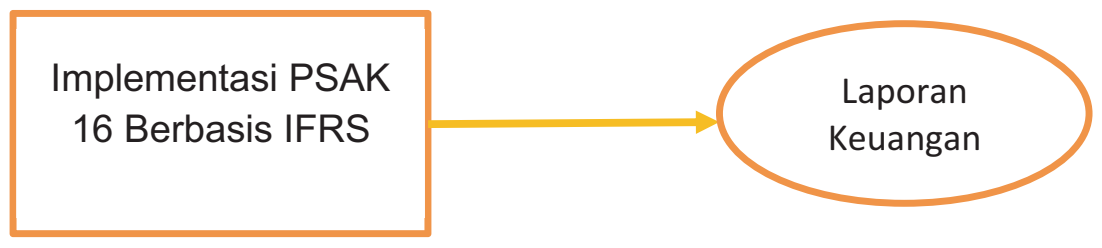




\subsection{Perumusan Hipotesis}

IAS 16 merupakan standar yang mengatur pelaporan aset tetap dalam laporan keuangan. Jadi implementasi IAS 16 dinilai dengan menganalisa kebijakan akuntansi terkait aset tetap yang diterapkan oleh perusahaan apakah sudah sesuai dengan ketentuan yang ada dalam IAS 16 serta bagaimana konsistensi penerapannya. Konsistensi yang dimaksud adalah apakah implementasi IAS 16 dalam suatu perusahaan dilakukan secara berkesinambaungan atau berkelanjutan. Berdasarkan uraian diatas maka penelitian ini akan melakukan telaah atas implementasi IAS 16 terhadap laporan keuangan Perbankan BUMN.

\section{METODOLOGI PENELITIAN}

Penelitian ini bersifat ekploratif yakni melakukan pengamatan terkait penerapan PSAK 16 pada perusahaan industri perbankan di Indonesia. Data sekunder mengenai laporan keuangan perusahaan perbankan diperoleh melalui akses internet, kemudian dilakukan analisis/interprestasi yang rasional dan akurat sehingga dapat membuat kesimpulan dan rekomendasi dengan membandingkan data yang ada dengan data yang relevan. Sampel yang digunakan dalam penelitian ini ditentukan secara purposive yakni sampel yang dipandang bisa mewakili perbankan Nasional. Dengan demikian sampel nya adalah seluruh bank pemerintah yang terdiri dari Bank Mandiri, Bank BNI, Bank Rakyat Indonesia (BRI) dan Bank Tabungan Negara (BTN) yang merupakan Badan Usaha Milik Negara (BUMN).

\section{Metode Analisis Data}

Dalam penelitian ini digunakan metode analisis deskriptif kualitatif. Analisis atas data dilakukan dengan menghimpun laporan keuangan pada periode pengamatan yakni tahun 2014 - 2015 untuk kemudian mendapatkan pemahaman atas implikasi IAS 16 pada setiap objek melalui analisis terhadap catatan atas laporan keuangan ataupun disclosure yang ada terkait dengan penerapan IAS 16 serta masalah lainnya yang berkaitan dengan pencatatan aset tetap yang dilaksanakan pada setiap bank BUMN tersebut. Pelaksanaan penelitian dimulai pada Bulan September 2016 dengan menghimpun data sekunder berupa laporan keuangan tahunan dari setiap bank yang akan diteliti. Serangkaian diskusi dilaksanakan melalui media elektronik maupun wawancara guna memperoleh konfirmasi tentang berbagai kendala yang dihadapi oleh manajemen pada waktu penerapan IAS 16

\section{ANALISIS DAN PEMBAHASAN}

Pembahasan dilakukan secara terperinci melalui laporan keuangan terutama dalam catatan atas laporan keuangan meliputi kriteria dalam pengakuan, pengukuran atau penilaian serta penyajian. Sebagai sumber data objek yang di gunakan adalah laporan keuangan Bank BUMN antara lain BNI (Bank Negara Indonesia), BRI (Bank Rakyat Indonesia), BTN (Bank Tabungan Negara), dan Bank Mandiri untuk tahun 2014-2015 yang sudah di audit oleh akuntan publik sehingga tingkat objektifitas informasi yang tersaji meyankinkan.

\section{BNI (Bank Negara Indonesia)}

Bank BNI memiliki kantor di berbagai negara seperti Indonesia, Malaysia, Singapura, Brunei, Fillipina, Papua Nugini, Jepang, Amerika Serikat, Inggris , Hong Kong, Britania Raya dan laporan keuangan 2014-2015 yang telah di audit oleh auditor independen dari Kantor akuntan publik Tanudiredja, Wibisana \& Rekan (PWC).

Aset tetap dinyatakan sebesar biaya perolehan dikurangi akumulasi penyusutan dan rugi penurunan nilai. Biaya perolehan termasuk biaya penggantian bagian aset tetap saat biaya tersebut terjadi, jika memenuhi kriteria pengakuan.Hal ini sudah sesuai dengan yang dinyatakan PSAK 16 pada paragraf 30 "setelah pengakuan sebagai aset, set tetap dicatat pada biaya perolehan dikurangi akumulasi penyusutan dan akumulasi rugi penurunan nilai." Seluruh biaya pemeliharaan dan perbaikan yang tidak memenuhi kriteria untuk dikapitalisasi diakui dalam laporan laba rugi pada saat terjadinya. Pada setiap akhir tahun buku, nilai residu, umur manfaat, dan metode penyusutan ditelaah kembali dan jika sesuai 
dengan keadaan, disesuaikan secara prospektif. Semua aset tetap seperti perlengkapan kantor terdiri dari perabotan dan perlengkapan, instalasi, Anjungan Tunai Mandiri (ATM), perangkat lunak dan perangkat keras komputer, peralatan komunikasi dan peralatan kantor lainnya, disusutkan berdasarkan metode garis lurus selama estimasi masa manfaat aset tersebut, hal ini telah sejalan dengan PSAK 16 paragraf 62.Semua biaya yang terjadi sehubungan dengan perolehan hak atas tanah, diakui sebagai biaya perolehan hak atas tanah. Biaya pengurusan legal hak atas tanah ketika tanah diperoleh pertama kali diakui sebagai bagian dari biaya perolehan aset tanah. Biaya pengurusan perpanjangan atau pembaruan legal hak atas tanah diakui sebagai aset tak berwujud dan diamortisasi sepanjang umur hukum hak atau umur ekonomis tanah, mana yang lebih pendek.Hak atas tanah tidak disusutkan kecuali terdapat bukti sebaliknya yang mengindikasikan bahwa perpanjangan atau pembaruan hak atas tanah kemungkinan besar atau pasti tidak diperoleh.Apabila aset tetap tidak digunakan lagi atau dijual, maka nilai perolehan dan akumulasi penyusutannya dihapuskan dari akun tersebut. Keuntungan atau kerugian yang terjadi diakui dalam laporan laba rugi.Perlakuan ini telah mengikuti PSAK 16 paragraf 67 "Jumlah tercatat aset tetap dihentikan pengakuannya: a) pada saat pelepasan; b) ketika tidak terdapat lagi manfaat ekonomik masa depan yang diharapkan dari penggunaan atau pelepasannya." Dan terkait pengalokasian keuntungan dan kerugian dari penjualan yang terjadi diatur dalam paragraf 68 "Keuntungan dan kerugian yang timbul dari penghentian pengakuan aset tetap dimasukkan dalam laba rugi ketika aset tetap tersebut dihentikan pengakuannya."Akumulasi biaya konstruksi aset tetap dikapitalisasi dan dicatat sebagai "Aset dalam Penyelesaian". Biaya tersebut direklasifikasi ke akun aset tetap yang terkait pada saat proses konstruksi atau pemasangan telah selesai.

Penjelasan diatas sesuai dengan ketentuan yang di atur dalam PSAK 16 paragraf 17 (a) "Contoh biaya yang dapat diatrubusikan secara langsung adalah: a) biaya imbalan kerja (sebagaimana didefinisikan dalam PSAK 24) yang timbul secara langsung dari konstruksi atau perolehan aset tetap."

Manajemen berkeyakinan bahwa tidak terdapat penurunan nilai aset tetap yang dimiliki bank selama tahun berjalan karena manajemen berpendapat bahwa nilai tercatat aset tetap tidak melebihi estimasi nilai yang dapat diperoleh kembali.Aset tetap Bank pada tanggal 31 Desember 2014 diasuransikan terhadap risiko kebakaran dan pencurian dengan nilai pertanggungan sebesar Rp7.671.356 (2013: Rp6.105.541). Manajemen berpendapat bahwa nilai pertangungan tersebut cukup untuk menutupi kemungkinan kerugian atas aset tersebut

Pada tanggal 31 Desember 2014 terdapat aset tetap yang sudah didepresiasi penuh namun masih digunakan yang nilainya sebesar Rp3.175.154 (2013: Rp3.212.190).

Penilaian pada nilai wajar tanah dan bangunan yang dimiliki Bank pada tanggal 31 Desember 2014 dan 2013 adalah dengan menggunakan nilai dari Nilai Jual Obyek Pajak (NJOP). NJOP dianggap sebagai estimasi terbaik yang mencerminkan nilai wajar. Pada tanggal 31 Desember 2014, NJOP tanah dan bangunan yang dimiliki Bank masing masing bernilai Rp4.452.810 dan Rp1.120.111 (2013: Rp2.892.696 dan Rp1.103.995). Selain tanah dan bangunan, tidak ada perbedaan yang signifikan antara nilai wajar aset tetap dengan nilai tercatatnya.

BNI 2015. Pada tanggal 30 September 2015, Grup melakukan perubahan kebijakan akuntansi atas tanah dan bangunan dari model biaya menjadi model revaluasi dan menerapkannya secara prospektif. Perobahan ini sudah mengacu pada PSAK 16 dalam paragraf 42(a) "Jika entitas mengubah kebijakan akuntansi dari model biaya ke model revaluasi dalam pengukuran aset tetap, maka perubahan tersebut berlaku secara prospektif.'Tanah dan bangunan disajikan sebesar nilai wajar, dikurangi akumulasi penyusutan untuk bangunan. Penilaian terhadap tanah dan bangunan dilakukan oleh penilai independen eksternal yang telah memiliki sertifikasi. Penilaian atas aset tersebut dilakukan secara berkala untuk memastikan bahwa nilai wajar aset yang direvaluasi tidak 
berbeda secara material dengan nilai tercatatnya. Akumulasi penyusutan pada tanggal revaluasi dieliminasi terhadap nilai tercatat bruto aset, dan nilai netonya disajikan kembali sebesar nilai revaluasian aset tetap.Semua biaya yang terjadi sehubungan dengan perolehan hak atas tanah, diakui sebagai biaya perolehan hak atas tanah. Biaya pengurusan legal hak atas tanah ketika tanah diperoleh pertama kali diakui sebagai bagian dari biaya perolehan aset tanah. Biaya pengurusan perpanjangan atau pembaruan legal hak atas tanah diakui sebagai aset takberwujud dan diamortisasi sepanjang umur hukum hak atau umur ekonomis tanah, mana yang lebih pendek.Hak atas tanah tidak disusutkan kecuali terdapat bukti sebaliknya yang mengindikasikan bahwa perpanjangan atau pembaruan hak atas tanah kemungkinan besar atau pasti tidak diperoleh.Apabila nilai tercatat aset lebih besar dari nilai yang dapat diperoleh kembali, nilai tercatat aset diturunkan menjadi sebesar nilai yang dapat diperoleh kembali, yang ditentukan sebagai nilai tertinggi antara harga jual neto dan nilai yang dipakai. Hal ini mengikuti ketentuan dalam PSAK 48 tentang impairment/penurunan nilai asset.

Manajemen berkeyakinan bahwa tidak terdapat penurunan nilai aset tetap yang dimiliki Grup selama tahun berjalan karena manajemen berpendapat bahwa nilai tercatat aset tetap tidak melebihi estimasi nilai yang dapat diperoleh kembali.

Aset tetap Bank pada tanggal 31 Desember 2015 diasuransikan terhadap risiko kebakaran dan pencurian dengan nilai pertanggungan sebesar Rp8.393.422 (2014: Rp7.671.356). Manajemen berpendapat bahwa nilai pertangungan tersebut cukup untuk menutupi kemungkinan kerugian atas aset tersebut. Penilaian atas tanah dan bangunan dilakukan oleh

penilai independen eksternal. Terjadi perubahan kebijakan akuntansi atas kelompok tanah dan bangunan yang termasuk dalam kelompok yang telah di atur dalam PSAK 16. Penilaian dilakukan berdasarkan Standar Penilaian Indonesia, ditentukan berdasarkan transaksi pasar terkini dan dilakukan dengan ketentuan-ketentuan yang lazim. Penjelasan diatas adalah terkait metode penentuan nilai yang dilakukan oleh penilai independen eksternal.

Penilaian kembali yang dilakukan atas tanah menghasilkan jumlah kenaikan nilai tercatat sebesar Rp10.565.500 yang terdiri dari kenaikan nilai tanah yang dicatat sebagai "Pendapatan Komprehensif Lain" sebesar Rp10.570.506 dan penurunan nilai tanah yang diakui sebagai beban tahun berjalan sebesar Rp5.006.Hal ini sesuai dengan yang di atur dalam PSAK 16 paragraf 39 .Kenaikan nilai tercatat yang timbul dari revaluasi bangunan dicatat sebesar Rp1.771.426. Kenaikan ini terdiri dari kenaikan nilai bangunan yang dicatat sebagai "Pendapatan Komprehensif Lain" sebesar Rp1.809.585 dan penurunan nilai bangunan yang diakui sebagai beban tahun berjalan sebesar Rp38.159. Bangunan sebesar Rp41.261 tidak mengalami perubahan nilai setelah dilakukan proses penilaian kembali.Secara total kenaikan nilai tercatat yang timbul dari revaluasi tanah dan bangunan dicatat sebagai "Pendapatan Komprehensif Lain" adalah sebesar Rp12.380.091. Penurunan nilai tercatat yang timbul dari revaluasi dicatat sebagai beban pada tahun berjalan adalah sebesar Rp43.165.

Tidak terdapat perpindahan antar tingkat selama tahun berjalan. Nilai wajar tingkat 2 dari tanah dan bangunan dihitung dengan menggunakan pendekatan perbandingan harga pasar, estimasi biaya reproduksi baru atau biaya pengganti baru, dan estimasi pendapatan dan biaya yang dihasilkan oleh aset. Harga pasar dari tanah dan bangunan yang paling mendekati disesuaikan dengan perbedaan atribut utama seperti ukuran aset, lokasi dan penggunaan aset. Input yang paling signifikan dalam pendekatan penilaian ini adalah asumsi harga per meter.

Selain tanah dan bangunan, tidak terdapat perbedaan yang signifikan antara nilai wajar aset tetap dengan nilai tercatatnya. 


\section{Bank Rakyat Indonesia (BRI)}

Sejak 1 Agustus 1992 berdasarkan Undang-Undang Perbankan No. 7 tahun 1992 dan Peraturan Pemerintah RI No. 21 tahun 1992 status BRI berubah menjadi perseroan terbatas. Kepemilikan BRI saat itu masih $100 \%$ di tangan Pemerintah Republik Indonesia. Setelah melalui banyak dinamika perkembangan, maka pada tahun 2003 Pemerintah Indonesia memutuskan untuk menjual 30\% saham bank ini, sehingga menjadi perusahaan publik dengan nama resmi PT. Bank Rakyat Indonesia (Persero) Tbk., yang masih digunakan sampai dengan saat ini. Bank BRI untuk tahun laporan keuangan 2014-2015 yang telah di audit oleh auditor independen dari Kantor akuntan publik Purwanto, Suherman \& Surja (EY).

Aset tetap awalnya diakui sebesar biaya perolehan, yang terdiri atas harga perolehan dan biayabiaya tambahan yang dapat diatribusikan langsung untuk membawa aset ke lokasi dan kondisi yang diinginkan supaya aset tersebut siap digunakan sesuai dengan maksud manajemen.

Setelah pengakuan awal, aset tetap dinyatakan pada biaya perolehan dikurangi akumulasi penyusutan dan akumulasi rugi penurunan nilai. Penyusutan aset dimulai pada saat aset tersebut siap untuk digunakan sesuai maksud penggunaannya dan dihitung dengan menggunakan metode garis lurus berdasarkan estimasi umur manfaat ekonomis. Penilaian aset tetap dilakukan atas penurunan dan kemungkinan penurunan nilai wajar aset jikaterjadi peristiwa atau perubahan keadaan yang mengindikasikan bahwa nilai tercatat mungkintidak dapat seluruhnya terealisasi.

Jumlah tercatat komponen dari suatu aset tetap dihentikan pengakuannya pada saat dilepaskanatau saat sudah tidak ada lagi manfaat ekonomik masa depan yang diekspektasikan dari penggunaan maupun pelepasannya. Laba atau rugi yang timbul dari penghentian pengakuan tersebut dimasukkan ke laba rugi untuk tahun dimana penghentian pengakuan tersebut dilakukan. Hal ini seturut dengan ketentuan dalam PSAK 16 paragraf 67

Nilai residu, umur manfaat dan metode penyusutan dievaluasi setiap akhir tahun dan disesuaikan secara prospektif jika diperlukan.Aset tanah dinyatakan sebesar biaya perolehan dan tidak disusutkan. Jika biaya perolehan tanah termasuk biaya pembongkaran, pemindahan dan restorasi lokasi, serta manfaat yang diperoleh dari pembongkaran, pemindahan dan pemugaran tersebut terbatas,maka biaya tersebut disusutkan selama periode manfaat yang diperolehnya. Dalam beberapa kasus, tanah itu sendiri memiliki umur manfaat yang terbatas, dalam hal ini, tanah tersebut disusutkan dengan cara yang mencerminkan manfaat yang diperoleh dari tanah tersebut. Beban pemeliharaan dan perbaikan dibebankan pada operasi pada saat terjadinya. Beban pemugaran dan penambahan dalam jumlah besar dikapitalisasi kepada jumlah tercatat aset tetap terkait bila besar kemungkinan bagi Kelompok Usaha manfaat ekonomi masa depan menjadi lebih besar dari standar kinerja awal yang ditetapkan sebelumnya dan disusutkan sepanjang sisa masa manfaat aset tetap terkait. Aset tetap dalam penyelesaian dicatat sebesar biaya perolehan, yang mencakup kapitalisasi. Beban pinjaman dan biaya-biaya lainnya yang terjadi sehubungan dengan pendanaan aset tetap dalam penyelesaian tersebut. Akumulasi biaya perolehan akan direklasifikasi ke akun "Aset Tetap" yang bersangkutan pada saat aset tetap tersebut telah selesai dikerjakan dan siap untuk digunakan. Aset tetap dalam penyelesaian tidak disusutkan karena belum tersedia untuk digunakan.

Biaya pengurusan legal hak atas tanah dalam bentuk Hak Guna Usaha ("HGU"), Hak Guna Bangunan ("HGB") dan Hak Pakai ("HP") ketika tanah diperoleh pertama kali diakui sebagai bagian dari biaya perolehan tanah pada akun "Aset Tetap". Biaya pengurusan perpanjangan atau pembaruan legal hak atas tanah diakui sebagai aset tidak berwujud dan diamortisasi sepanjang umur hak hukum atau umur ekonomi tanah, mana yang lebih pendek. Hal ini telah sesuai dengan ISAK 25 tentang Hak atas tanah

Manajemen BRI memperkirakan masa manfaat aset tetap berdasarkan periode dimana aset diharapkan akan tersedia untuk digunakan. Masa manfaat ekonomis aset tetap ditinjau 
secara berkala dan diperbarui jika memiliki ekspektasi yang berbeda dari perkiraan sebelumnya, yang terjadi karena kerusakan secara fisik dan teknis, atau keusangan secara komersial dan legal atau batasan lainnya atas penggunaan aset tersebut.

Jumlah penyusutan aset tetap yang dibebankan pada laporan laba rugi komprehensif konsolidasian adalah masing-masing sebesar Rp919.140 dan Rp678.285 untuk tahun yang berakhir pada tanggal tanggal 31 Desember 2014 dan 2013 .

BRI telah mengasuransikan aset tetap untuk menutup kemungkinan kerugian terhadap risiko kebakaran dan pencurian kepada PT Asuransi Bringin Sejahtera Artha Makmur (pihak berelasi) dan PT Asuransi Jasa Tania dengan nilai pertanggungan seluruhnya sebesar Rp9.101.785 dan Rp9.926.682 untuk tahun yang berakhir pada tanggal-tanggal 31 Desember 2014 dan 2013. Penilaian nilai wajar tanah dan bangunan yang dimiliki BRI menggunakan Nilai Jual Objek Pajak (NJOP), karena dianggap sebagai estimasi terbaik untuk mencerminkan nilai wajar. NJOP tanah dan bangunan yang dimiliki BRI pada tanggal 31 Desember 2014 masing-masing bernilai Rp3.374.000 dan Rp1.695.743, sedangkan pada tanggal 31 Desember 2013 masing-masing bernilai Rp2.715.330 dan Rp1.507.394. Selain tanah dan bangunan tidak terdapat perbedaan signifikan antara nilai wajar aset dan tercatatnya.

Manajemen berpendapat bahwa tidak terdapat penurunan nilai aset tetap dan jumlah nilai pertanggungan asuransi cukup untuk menutup risiko kerugian yang mungkin timbul atas aset tetap pada tanggal-tanggal 31 Desember 2014 dan 2013.

Jumlah penyusutan aset tetap yang dibebankan pada laporan laba rugi dan penghasilan komprehensif lain konsolidasian masing-masing sebesar Rp1.094.222 dan Rp919.140 untuk tahun yang berakhir pada tanggal-tanggal 31 Desember 2015 dan 2014 .

BRI telah mengasuransikan aset tetap (tidak termasuk hak atas tanah) untuk menutup kemungkinan kerugian terhadap risiko kebakaran, pencurian, vandalis, force majeur dan lain-lain kepada PT Asuransi Bringin Sejahtera Artamakmur dan PT Asuransi Jasa Tania dengan nilai pertanggungan seluruhnya sebesar Rp10.358.054 dan Rp9.101.785 untuk tahun yang berakhir pada tanggal-tanggal 31 Desember 2015 dan 2014. Penilaian pada nilai wajar tanah dan bangunan yang dimiliki BRI pada tanggal-tanggal 31 Desember 2015 dan 2014 adalah dengan menggunakan Nilai Jual Obyek Pajak (NJOP). NJOP dianggap sebagai estimasi terbaik untuk mencerminkan nilai wajar. NJOP tanah dan bangunan yang dimiliki BRI pada tanggal 31 Desember 2015 masing-masing senilai Rp3.711.881 dan Rp1.821.383 dan pada tanggal 31 Desember 2014 masing-masing senilai Rp3.374.000 dan Rp1.695.743. Selain tanah dan bangunan tidak terdapat perbedaan signifikan antara nilai wajar aset dan nilai tercatatnya. Nilai tercatat bruto aset tetap yang telah terdepresiasi penuh, namun masih digunakan oleh BRI adalah masing-masing sebesar Rp3.699.755 dan Rp3.178.943 pada tanggal 31 Desember 2015 dan 2014.

Manajemen berpendapat bahwa tidak terdapat penurunan nilai aset tetap dan jumlah nilai pertanggungan asuransi cukup untuk menutup risiko kerugian yang mungkin timbul atas aset tetap pada tanggal-tanggal 31 Desember 2015 dan 2014.

\section{Bank Tabungan Negara (BTN)}

Cikal bakal Bank Tabungan Negara adalah Postspaarbank yang berdiri pada tahun 1897. Pada tahun 1942, sejak masa pendudukan Jepang di Indonesia, bank ini dibekukan dan digantikan dengan Tyokin Kyoku atau Chokinkyoku. Setelah proklamasi kemerdekaan Indonesia bank ini diambil alih oleh pemerintah Indonesia dan diubah menjadi Kantor Tabungan Pos. Nama dan bentuk perusahaan selanjutnya berubah beberapa kali hingga akhirnya pada tahun 1963 diubah menjadi nama dan bentuk resmi menjadi Bank Tabungan Negara.

Laporan keuangan Bank BTN untuk tahun 2014-2015 yang telah di audit oleh auditor independen dari Kantor Akuntan Publik Purwanto, Suherman \& Surja (EY).

Seluruh aset tetap pada tahap awalnya diakui sebesar biaya perolehan, yang terdiri atas harga perolehan dan biaya-biaya tambahan yang dapat diatribusikan langsung untuk 
membawa aset ke lokasi dan kondisi yang diinginkan supaya aset tersebut siap digunakan sesuai dengan maksud manajemen.

Setelah pengakuan awal, aset tetap dinyatakan pada biaya perolehan dikurangi akumulasi penyusutan dan akumulasi rugi penurunan nilai.

Aset tetap yang diperoleh dalam pertukaran aset non-moneter atau kombinasi aset moneter dan non-moneter diukur pada nilai wajar, kecuali:

(i) transaksi pertukaran tidak memiliki substansi komersial, atau

(ii) nilai wajar dari aset yang diterima dan diserahkan tidak dapat diukur secara andal. Hal ini telah sesuai dengan PSAK 16 paragraf 24 .

Penyusutan bangunan dihitung dengan menggunakan metode garis lurus (straight-line method) sedangkan peralatan kantor dan kendaraan bermotor dihitung dengan menggunakan metode saldo menurun ganda (double-declining balance method) berdasarkan taksiran masa manfaat aset tetap sebagai berikut:

$\begin{array}{ll} & \text { Tahun } \\ \text { Bangunan } & 10-20\end{array}$

Peralatan kantor dan kendaraan bermotor 4-8

Penilaian terhadap aset tetap dilakukan jika terdapat kemungkinan penurunan nilai wajar dar sebuah aset atau jika terjadi peristiwa atau perubahan keadaan yang mengindikasikan bahwa nilai tercatat mungkin tidak dapat seluruhnya terealisasi. Perlakuan akuntansi ini telah selaras dengan PSAK 48.

Pada setiap akhir tahun buku, manajemen melakukan pengkajian ulang atas nilai residu, masa manfaat dan metode penyusutan dan disesuaikan secara prospektif. Hal ini sudah sesuai dengan PSAK 16 paragraf 51.

Tanah dinyatakan sebesar biaya perolehan dan tidak disusutkan dan jika biaya perolehan tanah termasuk biaya pembongkaran, pemindahan dan restorasi lokasi, serta manfaat yang diperoleh dari pembongkaran, pemindahan dan pemugaran tersebut terbatas, maka biaya tersebut disusutkan selama periode manfaat yang diperolehnya. Dalam beberapa kasus, tanah itu sendiri memiliki umur manfaat yang terbatas, dalam hal ini, tanah tersebut disusutkan dengan cara yang mencerminkan manfaat yang diperoleh dari tanah tersebut.

Beban pemeliharaan dan perbaikan dibebankan pada operasi pada saat terjadinya. Beban pemugaran dan penambahan dalam jumlah besar dikapitalisasi kepada jumlah tercatat aset tetap terkait bila kemungkinan manfaat ekonomi masa depan menjadi lebih besar dari standar kinerja awal yang ditetapkan sebelumnya dan disusutkan sepanjang sisa masa manfaat aset tetap terkait. Perlakuan ini telah sesuai dengan PSAK 16 paragraf 12

Aset tetap dalam penyelesaian dicatat sebesar biaya perolehan, yang mencakup kapitalisasi beban pinjaman dan biaya-biaya lainnya yang terjadi sehubungan dengan pendanaan aset tetap dalam penyelesaian tersebut. Akumulasi biaya perolehan akan direklasifikasi ke akun "Aset Tetap" yang bersangkutan pada saat aset tetap tersebut telah selesai dikerjakan dan siap untuk digunakan. Aset tetap dalam penyelesaian tidak disusutkan karena belum tersedia untuk digunakan.

Biaya pengurusan legal hak atas tanah dalam bentuk Hak Guna Usaha ("HGU"), Hak Guna Bangunan ("HGB") dan Hak Pakai ("HP") ketika tanah diperoleh pertama kali diakui sebagai bagian dari biaya perolehan tanah pada akun "Aset Tetap". Biaya pengurusan perpanjangan atau pembaruan legal hak atas tanah diakui sebagai aset tidak berwujud dan diamortisasi sepanjang umur hak hukum atau umur ekonomi tanah, mana yang lebih pendek.Bank memperkirakan masa manfaat aset tetap berdasarkan periode dimana aset diharapkan akan tersedia untuk digunakan. Masa manfaat ekonomis aset tetap ditinjau secara berkala dan diperbarui jika memiliki ekspektasi yang berbeda dari perkiraan sebelumnya, karena kerusakan secara fisik dan teknis, atau keusangan secara komersial dan legal atau batasan lainnya atas penggunaan aset tersebut. Selain hal tersebut, estimasi masa manfaat dari aset tetap didasarkan pada penilaian secara kolektif 
dengan menggunakan praktik industri, teknik evaluasi internal dan pengalaman dengan aset serupa.

Jumlah penyusutan aset tetap yang dibebankan pada tahun yang berakhir pada tanggal 31 Desember 2014 dan 2013 masing-masing sebesar Rp225.741 dan Rp279.446 . Nilai tercatat bruto dari aset tetap yang telah didepresiasi penuh oleh Bank namun masih digunakan adalah masing-masing sebesar Rp274.704 dan Rp271.091 pada tanggal 31 Desember 2014 dan 2013 .Penilaian nilai wajar tanah dan bangunan yang dimiliki oleh Bank menggunakan Nilai Jual Objek Pajak (NJOP), karena dianggap sebagai estimasi terbaik untuk mencerminkan nilai wajar. NJOP tanah dan bangunan yang dimiliki pada tanggal 31 Desember 2014 masing-masing bernilai Rp1.022.120 dan Rp452.721, sedangkan pada tanggal 31 Desember 2013 masing-masing bernilai Rp753.261 dan Rp448.071. Selain tanah dan bangunan tidak terdapat perbedaan signifikan antara nilai wajar aset dan tercatatnya.

Hak atas tanah terdiri dari hak milik dan hak guna bangunan. Manajemen berpendapat bahwa jangka waktu hak atas tanah dapat diperbaharui atau diperpanjang kembali.Bank telah mengasuransikan aset tetap kecuali tanah untuk menutup kemungkinan kerugian terhadap risiko kebakaran dan pencurian kepada PT Asuransi Bina Griya (pihak berelasi) pada tanggal 31 Desember 2014 sebesar Rp1.940.370 dan kepada PT Asuransi Bina Griya (pihak berelasi) dan PT Asuransi Ramayana Tbk pada tanggal 31 Desember 2013 sebesar Rp1.809.705.

Aset tetap awalnya diakui sebesar biaya perolehan, yang terdiri atas harga perolehan dan biaya-biaya tambahan yang dapat diatribusikan langsung untuk membawa aset ke lokasi dan kondisi yang diinginkan supaya aset tersebut siap digunakan sesuai dengan maksud manajemen. Penilaian aset tetap dilakukan atas penurunan dan kemungkinan penurunan nilai wajar aset jika terjadi peristiwa atau perubahan keadaan yang mengindikasikan bahwa nilai tercatat mungkin tidak dapat seluruhnya terealisasi. Hal ini mengacu pada PSAK 48 tentang impairment.Jumlah tercatat aset tetap dihentikan pengakuannya pada saat dilepaskan atau saat tidak ada manfaat ekonomis masa depan yang diharapkan dari penggunaan atau pelepasannya. Laba atau rugi yang timbul dari penghentian pengakuan aset (dihitung sebagai perbedaan antara jumlah neto hasil pelepasan dan jumlah tercatat dari aset) diperhitungkan dalam laporan laba rugi dan penghasilan komprehensif lain pada periode aset tersebut dihentikan pengakuannya.

Aset tetap dalam penyelesaian dicatat sebesar biaya perolehan, yang mencakup kapitalisasi beban pinjaman dan biaya-biaya lainnya yang terjadi sehubungan dengan pendanaan aset tetap dalam penyelesaian tersebut. Akumulasi biaya perolehan akan direklasifikasi ke akun "Aset Tetap" yang bersangkutan pada saat aset tetap tersebut telah selesai dikerjakan dan siap untuk digunakan. Aset tetap dalam penyelesaian tidak disusutkan karena belum tersedia untuk digunakan. Hal ini sudah mengikuti PSAK 16 paragraf 17 (a)

Jumlah penyusutan aset tetap yang dibebankan pada tahun yang berakhir pada tanggal 31 Desember 2015 dan 2014 masing-masing sebesar Rp196.358 dan Rp225.741.Nilai tercatat bruto dari aset tetap yang telah didepresiasi penuh oleh Bank namun masih digunakan adalah masing-masing sebesar Rp352.749 dan Rp274.704 pada tanggal 31 Desember 2015 dan 2014 .Penilaian nilai wajar tanah dan bangunan yang dimiliki oleh Bank menggunakan Nilai Jual Objek Pajak (NJOP), karena dianggap sebagai estimasi terbaik untuk mencerminkan nilai wajar. NJOP tanah dan bangunan yang dimiliki pada tanggal 31 Desember 2015 masing-masing bernilai Rp1.173.295 dan Rp491.857, sedangkan pada tanggal 31 Desember 2014 masing-masing bernilai Rp1.022.120 dan Rp452.721. Selain tanah dan bangunan tidak terdapat perbedaan signifikan antara nilai wajar aset dan tercatatnya.Bank telah mengasuransikan aset tetap kecuali tanah untuk menutup kemungkinan kerugian terhadap risiko kebakaran dan pencurian kepada PT Asuransi Bina Griya (pihak berelasi) pada tanggal 31 Desember 2015 dan 2014 masingmasing sebesar Rp2.495.418 dan Rp1.940.370. 


\section{Bank Mandiri}

PT Bank Mandiri (PERSERO) Tbk. merupakan bank terbesar di Indonesia dalam hal aset, pinjaman, dan deposit. Bank ini berdiri pada tanggal 2 Oktober 1998 sebagai bagian dari program restrukturisasi perbankan yang dilaksanakan oleh Pemerintah Indonesia. Pada bulan Juli 1999, empat bank milik Pemerintah yaitu, Bank Bumi Daya (BBD), Bank Dagang Negara (BDN), Bank Ekspor Impor Indonesia (Bank Exim), danBank Pembangunan Indonesia (Bapindo), digabungkan ke dalam Bank Mandiri.Setelah selesainya proses merger, Bank Mandiri kemudian memulai proses konsolidasi, termasuk pengurangan cabang dan pegawai. Selanjutnya diikuti dengan peluncuran single brand di seluruh jaringan melalui iklan dan promosi.Salah satu pencapaian penting adalah penggantian secara menyeluruh platform teknologi. Bank Mandiri mewarisi sembilan sistem perbankan dari keempat "'legacy banks"'. Setelah investasi awal untuk konsolidasi sistem yang berbeda tersebut, Bank Mandiri mulai melaksanakan program penggantian platform yang berlangsung selama tiga tahun, di mana program pengganti tersebut difokuskan untuk meningkatkan kemampuan penetrasi di segmen "'retail banking",.

Pada saat ini, infrastruktur teknologi informasi Bank Mandiri sudah mampu melakukan pengembangan "'e-channel", \& produk retail dengan "'Time to Market'" yang lebih baik. Sesudah menyelesaikan program transformasi semenjak 2005 sampai dengan tahun 2009, Bank Mandiri sedang bersiap melaksanakan transformasi tahap berikutnya dengan merevitalisasi visi dan misi untuk menjadi Lembaga Keuangan Indonesia yang paling dikagumi dan selalu progresif.

Pada Juni 2013, Bank Mandiri sudah mempunyai 1.811 cabang dan sekitar 11.812 ATM yang tersebar merata di 34 provinsi di Indonesia tanpa terkecuali, semakin menegaskan Bank Mandiri sebagai salah satu dari jajaran bank terbesar di Indonesia.Perusahaan perbankan BUMN yang terakhir akan di analisa adalah Bank Mandiri untuk tahun laporan keuangan 2014-2015 yang telah di audit oleh auditor independen dari Kantor akuntan publik Tanudiredja, Wibisana \& Rekan (PWC).

Aset tetap, kecuali tanah, dinyatakan sebesar biaya perolehan dikurangi akumulasi penyusutan dan penyisihan penurunan nilai. Biaya perolehan termasuk biaya penggantian bagian aset tetap saat biaya tersebut terjadi, jika memenuhi kriteria pengakuan aset tetap. Selanjutnya, pada saat inspeksi yang signifikan dilakukan, biaya inspeksi itu diakui ke dalam jumlah tercatat (carrying amount) aset tetap sebagai suatu penggantian jika memenuhi kriteria pengakuan. Semua biaya pemeliharaan dan perbaikan yang tidak memenuhi kriteria pengakuan diakui dalam laporan laba rugi komprehensif konsolidasian pada saat terjadinya. Perangkat lunak diakui sebagai aset tidak berwujud.

Penyusutan dan amortisasi dihitung dengan menggunakan metode garis lurus selama umur manfaat ekonomis aset tetap bersangkutan.

Jumlah tercatat aset tetap dihentikan pengakuannya pada saat dilepaskan atau saat tidak ada manfaat ekonomis masa depan yang diharapkan dari penggunaan atau pelepasannya. Laba atau rugi yang timbul dari penghentian pengakuan aset tetap (dihitung sebagai perbedaan antara jumlah neto hasil pelepasan dan jumlah tercatat dari aset tetap) dimasukkan dalam laporan laba rugi konsolidasian pada tahun berjalan aset tetap tersebut dihentikan pengakuannya.

Pada setiap akhir tahun buku, nilai residu, umur manfaat ekonomis dan metode penyusutan dikaji ulang dan jika tidak sesuai dengan keadaan akan disesuaikan secara prospektif.

Bank Mandiri menerapkan PSAK 16 tentang "Aset Tetap". dan memilih model biaya dan seluruh saldo nilai revaluasi aset yang masih dimiliki pada saat penerapan pertama kali PSAK 16, yang disajikan sebagai bagian dari ekuitas dalam laporan posisi keuangan konsolidasian sebesar Rp3.046.936, telah direklasifikasi ke saldo laba konsolidasian yang sudah ditentukan penggunaannya pada tahun 2008. 
Aset lain-lain antara lain terdiri dari pendapatan bunga dan provisi dan komisi yang masih akan diterima, tagihan, agunan yang diambil alih, properti terbengkalai, rekening antar kantor dan lain-lain.

Agunan yang diambil alih (AYDA) adalah aset yang diperoleh Bank Mandiri dan Entitas Anak, baik melalui pelelangan maupun diluar pelelangan berdasarkan penyerahan secara sukarela oleh pemilik agunan atau berdasarkan kuasa untuk menjual diluar lelang dari pemilik agunan dalam hal debitur tidak memenuhi liabilitasnya kepada Bank Mandiri dan Entitas Anak. AYDA merupakan jaminan kredit yang diberikan yang telah diambil alih sebagai bagian dari penyelesaian kredit yang diberikan dan disajikan pada "Aset Lainlain".

Aset yang tidak digunakan (properti terbengkalai) adalah aset tetap dalam bentuk properti yang dimiliki Bank Mandiri dan Entitas Anak, dimana bagian properti tersebut secara mayoritas tidak digunakan untuk kegiatan usaha operasional Bank Mandiri dan Entitas Anak.

AYDA dan properti terbengkalai disajikan sebesar nilai bersih yang dapat direalisasi (net realisable value). Nilai bersih yang dapat direalisasi adalah nilai wajar agunan yang diambil alih dikurangi dengan estimasi biaya untuk menjual AYDA tersebut. Kelebihan saldo kredit yang diberikan yang belum dilunasi oleh debitur di atas nilai dari AYDA, dibebankan terhadap Cadangan Kerugian Penurunan Nilai kredit yang diberikan. Selisih antara nilai bersih yang dapat direalisasi dengan hasil penjualan AYDA diakui sebagai keuntungan atau kerugian pada tahun berjalan pada saat dijual.

Beban-beban yang berkaitan dengan pemeliharaan AYDA dan properti terbengkalai dibebankan ke laporan laba rugi komprehensif konsolidasian tahun berjalan pada saat terjadinya. Bila terjadi penurunan nilai yang bersifat permanen, maka nilai tercatatnya dikurangi untuk mengakui penurunan tersebut dan kerugiannya dibebankan pada laporan laba rugi komprehensif konsolidasian tahun berjalan.

Aset tetap, kecuali tanah, dinyatakan sebesar biaya perolehan dikurangi akumulasi penyusutan dan penyisihan penurunan nilai. Biaya perolehan termasuk biaya penggantian bagian aset tetap saat biaya tersebut terjadi, jika memenuhi kriteria pengakuan aset tetap. Selanjutnya, pada saat inspeksi yang signifikan dilakukan, biaya inspeksi itu diakui ke dalam jumlah tercatat (carrying amount) aset tetap sebagai suatu penggantian jika memenuhi kriteria pengakuan. Semua biaya pemeliharaan dan perbaikan yang tidak memenuhi kriteria pengakuan diakui dalam laporan laba rugi dan penghasilan komprehensif lain konsolidasian pada saat terjadinya. Perangkat lunak diakui sebagai aset tidak berwujud.Biaya perolehan aset tetap disusutkan dengan menggunakan metode garis lurus berdasarkan taksiran masa manfaat ekonomisnya. Manajemen Bank mengestimasi masa manfaat ekonomis aset tetap antara 5 (lima) sampai dengan 20 (dua puluh) tahun. Perubahan tingkat pemakaian dan perkembangan teknologi dapat mempengaruhi masa manfaat ekonomis dan nilai sisa aset, dan karenanya biaya penyusutan masa depan mungkin direvisi, seturut dengan PSAK 16 paragraf 62.

Termasuk dalam pengadaan aset tetap dan perangkat lunak adalah utang kepada pemasok atau vendor terkait kegiatan operasional dan pemeliharaan gedung, peralatan, perangkat lunak, mesin ATM dan sistem Teknologi Informasi Bank.

\section{MANAJEMEN RISIKO}

Untuk menjamin fasilitas kredit, Bank mengutamakan agunan dalam bentuk aset tetap berupa tanah atau tanah berikut bangunan. Nilai agunan yang digunakan Bank sebagai jaminan kredit adalah nilai agunan yang dinilai oleh penilai internal (credit operation unit) dan penilai eksternal rekanan Bank atau penilai eksternal bukan rekanan Bank yang telah ditunjuk pejabat pemegang kewenangan di business unit/credit recovery unit. Agunan dapat ditukar selama masih memenuhi aspek marketabilitas dan memenuhi kecukupan nilai agunan. Jika terjadi gagal bayar oleh debitur, Bank akan melikuidasi agunan sebagai second way out guna menjamin pelunasan hutang debitur. 


\section{KESIMPULAN}

Berdasarkan hasil penelitian dan analisa yang telah dilakukan dalam penelitian ini, maka dapat disimpulkan bahwa implementasi PSAK 16 dalam perusahaan industri perbankan BUMN untuk tahun 2014-2015 dapat dilakukan dengan lancar meskipun terdapat kesulitan pada tahapan memastikan terjadi tidaknya impairment serta penetapan harga pasar yang valid. Secara umum bahwa di seluruh entitas perbankan BUMN sudah menerapkan PSAK 16 sesuai dengan yang semestinya. Hal ini juga merupakan hasil kerja manajemen serta adanya pengawasan yang sangat baik oleh regulator. Di Bank BNI untuk tahun 2015 telah mengganti metode biaya menjadi metode revaluasian, namun pelaksanaannya telah mengikuti ketentuan yang berlaku.

\section{DAFTAR PUSTAKA}

Ankarat, Nandakumar et al. 2012. Memahami IFRS : Standar Pelaporan Keuangan Internasional. Alih Bahasa : Priyo Darmawan. Jakarta : Indeks.

Bank Mandiri, http://www.bankmandiri.co.id/corporate01/about_profile.asp

Bank Negara Indonesia, http://www.bni.co.id/id-id/tentangkami/sejarah.aspx

Bank Rakyat Indonesia, http://www.bri.co.id/articles/9

Bank Tabungan Negara, http://www.btn.co.id/id/content/BTN-Info/TentangKami/Sejarah-Bank-BTN

Baridwan, Zaki. 2004. Intermediate Accounting, Edisi Kedelapan. Yogyakarta: BPFE

Enty Megawati, Suhadak, (2014) Penelitian di PT. Perkebunan Nusantara X (Persero) Pabrik Gula Meritjan Kediri,

Erwin Budiman, Sifrid Pangemanan, dan Steven Tangkuman (2014) Penelitian di PT. Hasjrat Multifinance Manado

Harrison, Walter T., 2012. Akuntansi Keuangan, edisi kedelapan, Jilid I. Jakarta : Erlangga

Ikatan Akuntan Indonesia, 2015, Standar Akuntansi Keuangan, Cetakan pertama oleh Penerbit IAI International Accounting Standard Boards. 2012. International Acounting Standard No. 16, Property, Plant and Equipment.

Kieso Weygandt, 2014, Intermediate Accounting, Wiley, Second Edition

Pascale Lapointe (2011), The Implementation of IAS 16 and IAS 41 at Andrew Peller Limited, Canada

Purba, Marisi. 2013. Aset Tetap dan Aset Tak Berwujud. Yogyakarta : Graha Ilmu.

Rudianto. 2012. Pengantar Akuntansi. Jakarta : Erlangga.

Sarah E Monday 2009, IAS 16 and the Revaluation Approach; Reporting Property, Plant \& Equipment at Fair Value, University of Tennessee 

